\title{
Miranda
}

Revue pluridisciplinaire du monde anglophone /

Multidisciplinary peer-reviewed journal on the English-

speaking world

$14 \mid 2017$

Early American Surrealisms, 1920-1940 / Parable Art

\section{An Interview with Oku Onuora}

\section{Eric Doumerc}

\section{OpenEdition}

\section{Journals}

Electronic version

URL: http://journals.openedition.org/miranda/10061

DOI: 10.4000/miranda.10061

ISSN: $2108-6559$

\section{Publisher}

Université Toulouse - Jean Jaurès

\section{Electronic reference}

Eric Doumerc, "An Interview with Oku Onuora", Miranda [Online], 14 | 2017, Online since 18 April 2017 connection on 16 February 2021. URL: http://journals.openedition.org/miranda/10061 ; DOI: https:// doi.org/10.4000/miranda.10061

This text was automatically generated on 16 February 2021.

\section{$\Theta \Theta \Theta \Theta$}

Miranda is licensed under a Creative Commons Attribution-NonCommercial-NoDerivatives 4.0 International License. 


\title{
An Interview with Oku Onuora
}

\author{
Eric Doumerc
}

\section{The Context:}

1 Oku Onuora is considered as one of the founders of the dub poetry movement and, together with Mutabaruka, the late Mikey Smith and Linton Kwesi Johnson, he has inspired many dub poets both in the Caribbean and in Europe.

2 The following interview was conducted on 15 August 2016 at the Jamaica School of Drama, the very place where Oku Onuora and other dub poets studied in the 1970s.

\section{Biography of Oku Onuora:}

Oku Onuora (Orlando Wong) was born in 1952 in Jamaica and grew up in Franklin Town, a working-class area in Eastern Kingston. After robbing a post office in 1970, he was given a 15-year jail sentence, but was eventually released in 1977, partly because of the success of his poetry. Onuora had started writing in prison and had gradually made his name as a poet. In 1974 the prison authorities allowed him to read his poems accompanied by Cedric Brooks's band, the Light of Saba. In 1977, his first collection of poems, Echo (Kingston: Sangster's, 1977) was published to great popular and critical acclaim, and his first recording, "Reflection in Red", soon followed. His first LP, Pressure Drop, was released on the French Blue Moon label in 1985, which led to extensive touring in Europe and in the Caribbean. Since then, he has released several recordings, like Buss Out (1993) and A Movement (2013).

\section{The Interview}

\section{An interview with Oku Onuora}


Eric Doumerc: I'm not going to ask you the usual questions about dub poetry or about yourself, because, quite frankly, your biography is well-known, like how you were jailed and then got out of jail thanks to the efforts of Professor Mervyn Morris and other academics...

Oku Onuora: Professor Mervyn Morris was the only UWI [University of the West Indies, author's note] academic. Barbara Gloudon, a journalist, and Leonie Forbes, an actress, you know, they were prominent. I'd be clear, you know, because I've been known to burn out academics because I believe they're a bunch of hypocrites. Mervyn Morris is a beautiful person. I don't fight against academia as such, because I coached my children to seek higher education and all of that stuff, but for the most part, I believe that academia are a bunch of sell-outs, you know. Most of them are not for the people. You are for the people or you are against the people.

ED: In Jamaica?

Oku Onuora: Yes, in Jamaica and globally. All over the world, it's like that. They tend to reflect, you know, the ideas of the ruling class. But they've always been powerful in the people's struggle, you know. When people from academia, when professional people become a part of the movement, then it adds to it.

ED: You were jailed for seven years and that's when you started writing poetry, or did you start before?

Oku Onuora: No, it was while in prison that I started to write seriously. Prior to that, I probably had written one or two poems, but I had never really like taken up writing.

ED: When you started writing in prison, were you aware of the work being done by reggae deejays like U-Roy, I-Roy and Big Youth?

Oku Onuora: I was aware of them, but I was influenced by people like Bob Marley, Peter Tosh, Burning Spear. Even growing up, I was never seriously a deejay fan. I love deejay music, people like Big Youth, U-Roy. They are great. But for me Bob Marley is one of the greatest poets. People like Bob Marley, Peter Tosh and Burning Spear were the people who influenced me as a writer.

ED: So, when you were jailed, you had already come under the influence of these people.

Oku Onuora: Yes! Because I was a young adult when I went to prison, but I had attended a number a dances, so I had a musical taste and preference.

ED: Regarding Burning Spear, do you remember any particular song or album that you liked?

Oku Onuora: I love "Foggy Road"! It's simple, a repetition, I believe it's a masterpiece! And then "Marcus Garvey" is an excellent piece of work!

ED: So you have coined the phrase "dub poetry". There's so much confusion...

Oku Onuora: Yes, there's so much confusion! Let me say it and I've said it more than once! There's no need to coin the phrase "dub poetry" because, prior to me using the phrase "dub poetry", we had the phrase "overdub", "dubbing", "dubplate"; and then the words "dub poetry" came about while I was in prison and I would come out in the morning and this brother realised that I was writing poetry and all of that and he would say "Come on! Dub a t'ing! Dub a piece of poem!" And I wanted to distinguish myself from the normal poetry! I wanted to distinguish myself from all these people, Miss Lou [Louise Bennett, author's note], Chaucer, Shakespeare. There's nothing wrong with Miss Lou, but I was doing something different than Miss Lou, you know. Miss Lou, she was using a lot of humour, she was using a folk rhythm. You know, I see Miss Lou as a folk poet rather than as anything else. And when I looked at what I was 
doing, I said to myself: "Wow, it's a process of dubbing". Because my aim and objective was, is to dub out some unconsciousness, and dub in some consciousness. I dub in the reggae rhythm into my poetry: the rhythm of my poetry is reggae. And other forms of music, jazz...

\section{ED: So, it's not limited to reggae.}

Oku Onuora: No, it's a dubbing process. It is what makes it unlimited. And then, after I described what I was doing, someone pointed out that Linton had used the phrase. But, after that, I read the article, because I did not read the article prior to describing myself as a dub poet. Because it's a common thing in Jamaica... Big Youth's Reggae Give Them Dub... For example, "dub your girl", like that slow wine on a woman, it's called "dubbing", "rub-a-dub style". So Linton had an article in Race Today where he was describing the deejays as dub poets and that's too much of a different thing! He had never used the phrase to describe poets as such. He was describing the deejays as dub poets. I didn't read that article until it was brought to my attention because we don't get Race Today here in Jamaica.

But I am a dub poet, I don't need to coin the phrase: I am the first Jamaican poet whether here or in Britain, to use that phrase to describe my poetry, not a deejay, 'cause I am not a deejay, [I am] a dub poet to be specific. In fact, Linton was introduced to I and I was introduced to Linton at the same time, by the same person, Mervyn Morris, and when he met Linton, he said to Linton, "Wow, there's a brother in Jamaica, and you remind me of him, you do some similar kind of work". And then Mervyn came back from the UK and said: "Wow, I've met a brother by the name of Linton Kwesi Johnson..." And I can categorically and safely say that I did not hear Linton talk about dub poetry when I used the phrase. Using the phrase "dub" as a prefix is something common in Jamaica, you know, like "dub the boy!", meaning "beat the boy!"; "dub a girl", meaning wine on her; "dubplate". So dub poetry falls into place! 'Cause in Jamaica, dubbing is a must: we've always talked about dub since the days when we had the A side and the B side, which we called the "dub side".

ED: How did you work with Mervyn Morris on your first collection, entitled Echo? Did you read the poems to him or give him a transcript?

oku Onuora: I gave him a transcript and we selected from that. So Mervyn did not do any kind of editing, because if you know my Jamaican English, it's more akin to the phonetic spelling of the words.

\section{ED: So, Mervyn Morris did not have any input in terms of the orthography.}

Oku Onuora: No, he'd make some suggestions here and there, but, no, what Mervyn actually did was to assist me in putting my first collection of poems, Echo, together and having it published. I met Mervyn via Leonie Forbes, a beautiful Jamaican actress, radio journalist and TV personality. At first, my poems were exposed to Barbara Gloudon. Barbara Gloudon is an excellent woman. At the time, she had a column in the Saturday Star and I always looked out for her piece. It was called "Stella" and it was written in the Jamaican language. It dealt with socio-political issues and I was eager to read that column because she was addressing socio-economical issues. So I communicated with her while I was in prison and I sent her my poems. The first time one of my poems appeared in a public paper was because of the influence of Barbara Gloudon. She had my work published in The Gleaner. At one time she became the first female editor of a major paper here in Jamaica. She has written several pieces for the Jamaican Pantomime. So she passed on my work to Leonie Forbes who passed it on to 
Mervyn Morris and when Mervyn got them Mervyn came to visit me and we talked about my work. What I love about Mervyn is that Mervyn did not try to alter or change my poems. He gave me some useful pointers, some suggestions, and he assisted me in selecting the poems for Echo and I took his suggestions. Mervyn did not come with any kind of academic air. He just came as a poet. In recent times, I'm realising why we are so similar, why Mervyn likes my work, because my work is concise. I write short poems. And Mervyn is like that: he writes very concise poems.

\section{ED: What kind of reception did Echo get in Jamaica?}

Oku Onuora: Echo spent five weeks number one on the best-sellers' list in the Sunday Gleaner. In less than a year, it went through about three or four reprints. The Tom Redcam Library complained because when my book was placed on the shelves, people would borrow it and not return it. There were reports of people downtown pushing handcarts with copies of my book in their back pocket. It was extremely popular because it resonated with the Jamaican people. In 1976 I entered three poems in the literary segment of the Jamaica Festival Competition and the three poems received awards. In 1977 I entered three poems and I won three awards in three different categories. The judges in the literary competition who were judging these poems could recognise the reggae rhythm coming out of the poems. Because, to be truthful, I am a frustrated singer. I love to sing, but I don't have a singing voice, so I use my speaking voice. When I do a piece, I hear music in my head. So for instance when I did a piece on my debut album like "Thinking" and "Thinking" is dub, it's jazz! I was invited to the Angoulême Jazz Festival.

ED: What about the experience of recording your first album, Pressure Drop? How did you hook up with all these musicians?

Oku Onuora: My first recording, "Reflection in Red", I did it with Steve Golding, excellent musician, guitarist extraordinaire. So I recruited Steve Golding and he actually selected the rest of the musicians. Cedric Im Brooks played percussion. Then I did "Dread Times", "What a Situashan" and "I a Tell".

By the time I did my debut album, I was well seasoned as a producer because I had already produced my work. I'm an independent producer, from my debut single to my debut album, because I'm talking about self-reliance, and if you're talking about self-reliance and certain things, then you should walk the walk and talk the talk! That's what I believe in: your work should be an example of your ideology, what you talk about. So by the time I was ready to do my debut album, I was well seasoned as a producer, so I selected young musicians, very young musicians. These people were not known at the time but I selected them because I knew them personally and I knew what they were doing. For example, my bass player, Courtney Panton, when I first met him, he was a known percussionist. When I met him, he was playing percussion over by the Jamaica School of Dance and then after a while he started to play the bass. So when I was recruiting musicians for AK7, I was looking for young musicians to interpret the work I was doing as opposed to musicians who were set in their ways, brilliant nonetheless, but that time I said: "I want to use some fresh talent". So I started to look around: Courtney Panton, and he had a friend by the name of Hewlitt, a drummer. One of the guitarists was named Simon. I met Simon when he had just graduated from JC [Jamaica College, author's note]. He was familiar with my work and my wife used to teach him when he was at school. He was with a group of young musicians and Chinna [Earl Chinna Smith, author's note], Chinna is 
an awesome teacher, had all these musicians around him. So I knew Simon from that time and he'd always wanted to play with me. Hugh Pape is an awesome person and an awesome musician: he plays the saxophone, he plays the flute and I met him while I was attending the Jamaica School of Drama. He played the flute on "What a Situashan" and the saxophone and the flute on Pressure Drop. The only seasoned musician at the time was Ras Bonito, who played lead guitar. Carl, who played keyboard, was a young musician, but he was involved in theatre as an actor, but playing music also. These are seasoned musicians today. For example, Courtney Panton went on to play for Shaggy and he toured extensively. He has a band called New Kingston. Simon went on to play for a number of musicians. Carl isn't playing music anymore; he actually teaches drama. Musa isn't playing music anymore: he's more into producing for cable television.

ED: One question about "Dread Times", one of your most powerful pieces. When you wrote that poem, what was going on in your head?

Oku Onuora: All poems on Pressure Drop came from my debut collection, Echo. Generally, the poems from Echo reflect the conditions that lead the youth to prison, and "Dread Times" was written at that time when we were going through some serious economical problems in Jamaica. It's an echo from what I heard. It was like a daily occurrence in the life of the average Jamaican.

ED: The poem entitled "Decolonisation", with its djembe drumming, reminds me of what the Last Poets were doing in the early 1970s.

Oku Onuora: Actually, that piece was not slated for recording. While I was in the studio working on Pressure Drop, I was informed by the guard (I was doing this at Tuff Gong Studios) that there was someone there to see me. His name was Olumede and he was from America. When he came in, I realised he's a friend of someone I knew from New York who has an African drumming and dance group. So Olumede heard that I was recording an album and he actually came to Jamaica on his own, and he said to me: "Oku Onuora, I'd like to play on your album" and I said: "Wow! We are recording and everything's slated...", but then from this brethren travelling so far and his desire to be on my album, I said to him that we would record something on the next day. So he went away, and this poem came to me: "Decolonisation" and I thought: "Lemme read this poem on this riddim". So when he came in, I said: "There's a poem I'd like both of us to do". So he listened to the poem once and then he started to play. So that was the first poem we recorded that night. And this is what I believe in, to this very day: it's still relevant, even more relevant than before, especially at this time of the year, you know, it comes to mind. We talk about independence, but getting a flag and an anthem from the British colonialists doesn't make us really free.

ED: Your poem entitled "I Write About" came out of a confrontation with the prison authorities.

Oku Onuora: Yes, for the second time, my poetry was confiscated by the prison authorities and I was summoned to the Superintendent's office and he said to me: "Why you write so much poems about blood?" and I said: "Well, it's just inspiration..." So I went to my cell and that night the poem came.

ED: I understand you met Michael Smith at the Jamaica School of Drama.

Oku Onuora: The first time I met Michael Smith was at the Tom Redcam Library, when I did my first public reading and he approached me and said: "I write poetry" and I said to him: "You can visit me at the Fort Augustus prison", 'cause at the time I 
was at the Fort Augustus prison and things were kinda relaxed: I could receive visitors. In fact, that's where I got my first typewriter from Judy Mowatt. Mervyn used to come there too. It was during a period when the prison authorities couldn't block me anymore; they had to work with me, because there were people on the outside rooting for me, people like Barbara Gloudon, Mervyn Morris... So Mikey visited me and he showed me a version of "Mi Cyaan Believe It". Then we met again at the Jamaica School of Drama.

\section{ED: Was he already performing at the time?}

Oku Onuora: He wasn't really performing at the time. He was writing. When I came from prison in 1977, I was in demand, because of what Mikey did, and the socialist movement, the democratic socialist movement was at its zenith. Michael Manley was in power and you had the Workers' Party of Jamaica, and culture was being used by the socialist movement, like the PNP [People's National Party, author's note] Youth Movement. So the socialist movement was at its height and this is where Mikey and I continued our friendship. But we first met at the Tom Redcam library. Likewise I first met Linton in my audience. The first time I became aware of Mutabaruka was in my audience. I did a reading once at the Creative Arts Centre at UWI and while I was reading there was this baby crying and people were like "Shhh!" This was Mutabaruka and his wife's baby, their first daughter, and she was crying. And I said: "No, let the child cry 'cause that's music to my ears!" And I said: "When I leave you to go back to hell it's gonna be weeping and wailing and gnashing of teeth, so this baby crying is music to my ears!" So the first time I met Mutabaruka he was in my audience. Mikey was at my first reading. I had never seen Linton perform before I started to perform.

ED: There was a poet at the Drama School called Noel Walcott.

Oku Onuora: Yeah, man! Godfather Noel Walcott! We call him Godfather or Jahfather.

\section{ED: Whatever happened to him?}

Oku Onuora: He's around, you know, he's not doing poetry that much. You know, I hear people talk about the "dub poetry movement" at the Drama School as if a movement started at the Drama School. It was no Drama School movement. It was developed while I was here, but I was always different in terms of my recording, totally, totally, totally different, but Michael Smith was awesome! For me, it was a pleasure to see Mikey, to hear Mikey, to perform with Mikey and we had this synergy, Mikey and I. I haven't seen anyone like Mikey today, you know.

ED: Three years ago, you released a new album entitled A Movement, with Sly and Robbie, and Monty Alexander.

Oku Onuora: You know, A Movement for me was just an experimental album, because I revisited a number of my pieces, pieces that I had recorded before without music. I took poems that I had on my debut album and I put music to that. The album was only released on line, but a number of people are familiar with it in Jamaica. I didn't really promote it that much here in Jamaica for a number of reasons, 'cause it was signalling my re-emergency 'cause I had taken a hiatus from the music scene because I didn't like what was actually taking place here in Jamaica. The music had changed a lot. And I didn't want to get involved. And even before that, the musical world, the progressive musical world of uplifting, conscious music was subverted: there was a subversion that took place, you know, because we had Margaret Thatcher, we had 
Ronald Reagan, and disco music became the trend. This is the era when Jamaican deejay music became prominent, during that time, because music plays an important role in influencing people's consciousness. Music is a powerful tool, is a powerful means of conveying sentiment, an ideology, telling a story. It transcends border, it transcends language. This is one of the reasons I decided to use music to reach out, because initially I saw myself as becoming an investigative journalist. When I was writing my poetry in hell, I did that to release energy, this pent-up anger, because I had escaped twice before, you know, and the second time I escaped, I was shot. Initially, I didn't see myself becoming a poet, a published poet or a recording poet. I saw myself becoming an investigative journalist. In fact, I started to do a course from ICS (International Correspondence School) in Creative Writing while I was in hell.

ED: On that album, A Movement, you worked with a new dub poet called Jawara Ellis.

Oku Onuora: Jawara is the son of Owen "Blacka" Ellis. The first time I actually met Blacka, we sat under that very same Tree of Life. Blacka at the time was a student at the Jamaica School of Drama. Blacka was one the original members of AK7: he played percussions, and he did vocals, harmony. On my debut tour with AK7, Blacka was there. So Jawara grew up on it. So I had put A Movement together, and his father visited me and he said he wanted me to listen to something. So I listened and I heard the intro to "Sketches" and the poem came up! It blew my mind! And I felt so honoured to have a young poet sample my work, to be inspired by my work. I had never done that before, and I decided to use it on my album. So when Owen brought "Utter Sketches" to me, I realised the reason I was waiting was for this thing, because the album is called A Movement, and it speaks about the movement continuing and it also speaks about the movement from one generation to the next generation, a continuation. And my daughter has a piece on it called "Atomic", a poem she read at her mother's sending-off.

ED: This leads us to the new generation of dub poets in Jamaica. What about the new dub poetry scene? Is it very strong?

Oku Onuora: Yeah, man! It's strong! People like Jawara, people like Maker (a female dub poet), people like Sage, it's very strong. We have people like Ras Takura. We have Neeto Mix. Other people may not notice, but for me, it's very vibrant. When Mikey Smith was about, it was just Mikey Smith and a few other people. Now, poetry is bubbling in Jamaica, not necessarily dub poetry, but poetry, spoken word. Spoken word in Jamaica is really up and running right now.

\section{ED: Is Oku Onuora a happy man or an angry man?}

Oku Onuora: Yeah man! I'm happy! I'm not angry. I get angry when I look around and I see the conditions that we're in, not just here in Jamaica, but internationally, I get very, very angry. But I don't stay angry. There's a lot of things for me to be happy about. I am blessed, I am thankful, grateful, because I am surrounded and loved by people from near and far. The world is a wonderful place; it's just the system and some people. 


\section{ABSTRACTS}

Interview with Oku Onuora, who is considered as one of the founders of dub poetry. The interview was conducted on 15 August 2016 at the Jamaica School of Drama.

Entretien avec Oku Onuora, considéré comme l'un des fondateurs de la dub poetry. L'entretien a été réalisé le 15 août 2016 à la Jamaica School of Drama.

INDEX

Subjects: Arts of the Commonwealth

Keywords: dub poetry, orality, Caribbean poetry, reggae

Mots-clés: dub poetry, oralité, poésie des Caraïbes, reggae

\section{AUTHORS}

\section{ERIC DOUMERC}

Maître de conférences

Université de Toulouse - Jean Jaurès

doumerceric@neuf.fr 